\title{
Relationship of horse temperament with breed, age, sex, and body characteristics: a questionnaire-based study
}

\author{
Naglaa M. Abdel-Azeem * ${ }^{*}$ and H. H. Emeash
}

\begin{abstract}
Background: Temperament is an important issue that must be taken into consideration when purchasing horses for leisure, racing, or even work in the fields. Those who work with horses have various opinions about the relationship between a horse's body characteristics and its temperament, but few scientific papers on this issue have been published. The objective of this study was to clarify the relationships of horse temperament with sex, breed, age, and body characteristics to help purchasers when selecting a horse with the desired temperament. A web-based survey consisting of a 32-item questionnaire was used to clarify the associations of sex, breed, age, and body characteristics with a horse's temperament. The owners of a total of 112 horses from different countries (Egypt, Jordan, Palestine, and Iraq) were recruited to fill in the questionnaire about their horses.

Results: The results showed statistically significant associations of sex and breed with temperament with $89.7 \%$ and $108.3 \%$, respectively ( $p$ values $<0.001$ ), while there was no significant association between age and temperament (chi-square $p$ value 0.58 ). The results also clarified significant associations between body characteristics (color, head and body marks, leg marks, and whorls) and temperament (all chi-square p-values $<0.001$ ).

Conclusion: Purchasers can predict a horse's temperament from its sex, breed, and body characteristics, including coat color, body and leg marks, and whorls
\end{abstract}

Keywords: Horse, Temperament, Questionnaire, Mark, Whorl

\section{Background}

Temperament makes an individual unique, and it reflects patterns of thought, behavior, and emotion [1]. It was defined by Helmbrecht Howard [2] as the novel personality of a horse, as measured by observable behavioral characteristics.

A good understanding of horses' temperament may help when selecting horses for a particular use [3]. Hennessy et al. [4] demonstrated that, when selecting horses, purchasers prioritize temperament rather than performance, competitiveness, and exercise. In addition, Patricia et al. [5] clarified that riders are willing to pay more for a horse that has been tested for its temperament.

\section{* Correspondence: naglaa.mohamed@vet.bsu.edu.eg}

Department of Animal and Poultry Management and Wealth Development, Faculty of Veterinary Medicine, Beni-Suef University, Beni-Suef 62511, Egypt
Moreover, many horses for either leisure use or horseracing are sold despite an undesirable temperament [6]. Against this background, it would be beneficial to purchasers if the temperament of horses could be predicted from their body characteristics.

Increased scientific interest has been directed toward the subject of evaluating equine temperament. A questionnaire survey is one method that would be effective to assess this [7]. Although there is a growing literature on the temperament of horses, very little scientific work has focused on the association between a horse's temperament and its body characteristics.

The objective of this study is to clarify the relationships of a horse's temperament with its sex, breed, age, and body characteristics to help purchasers to select horses with the desired temperament.

\section{Springer Open}

(- The Author(s). 2021 Open Access This article is licensed under a Creative Commons Attribution 4.0 International License, which permits use, sharing, adaptation, distribution and reproduction in any medium or format, as long as you give appropriate credit to the original author(s) and the source, provide a link to the Creative Commons licence, and indicate if changes were made. The images or other third party material in this article are included in the article's Creative Commons licence, unless indicated otherwise in a credit line to the material. If material is not included in the article's Creative Commons licence and your intended use is not permitted by statutory regulation or exceeds the permitted use, you will need to obtain permission directly from the copyright holder. To view a copy of this licence, visit http://creativecommons.org/licenses/by/4.0/. 


\section{Methods}

A web-based survey consisting of a 32-item questionnaire was applied. The owners of a total of 112 horses from different countries (Egypt, Jordan, Palestine, and Iraq) were recruited to fill in the questionnaire about their horses. Duplicated and carelessly completed questionnaires were excluded from the study. A copy of the questionnaire is available on request from the corresponding author.

\subsection{Questionnaire design}

The questionnaire consisted of three parts with a total of 32 questions. Part A collected general information about the horse's name, breed, age, and sex. Part B was about the characteristic features of the horse (color, marks on head, body, and legs, whorls). Part C contained questions about the horse's temperament. The questionnaire was released online in both Arabic and English. Cornell University Horse Temperament Survey (College of Agriculture and Life Sciences, Department of Animal Science) was used as a guide for Part $\mathrm{C}$ of the questionnaire.

\subsection{Procedure}

For the evaluation, an online version of the survey was created with Google Forms. Before starting the survey, the participants were informed about the purpose of the study and that data would be treated anonymously and confidentially.

From January 2016, the questionnaire was available online at https://docs.google.com/forms/d/1EW21 I8frOf6-KH2RpWZCsNu5M3U7vlkAnAwQGoQTeOs/ edit? $=0 \& w=1 \#$. Social media was used to recruit participants. Personal visits to some farms were also performed.

\subsection{Statistical analysis}

Data were compiled, entered into Microsoft Excel, and then analyzed using SPSS version 20. The reliability of the questionnaire was first assessed to determine its robustness for this study. Descriptive statistical analyses were performed to describe the information obtained from the questionnaire. Chi-squared test was used to analyze the categorical variables.

\section{Results}

Analysis of the data revealed that the questionnaire was reliable (alpha $=0.8291)$. The owners who responded to the questionnaire items in the correct manner numbered 85 from a total of 112 respondents, after excluding the carelessly filled in and duplicated ones. Figure 1 shows the numbers and proportions of horses included in the study by sex: $53.9 \%$ were male and $41.6 \%$ were female.

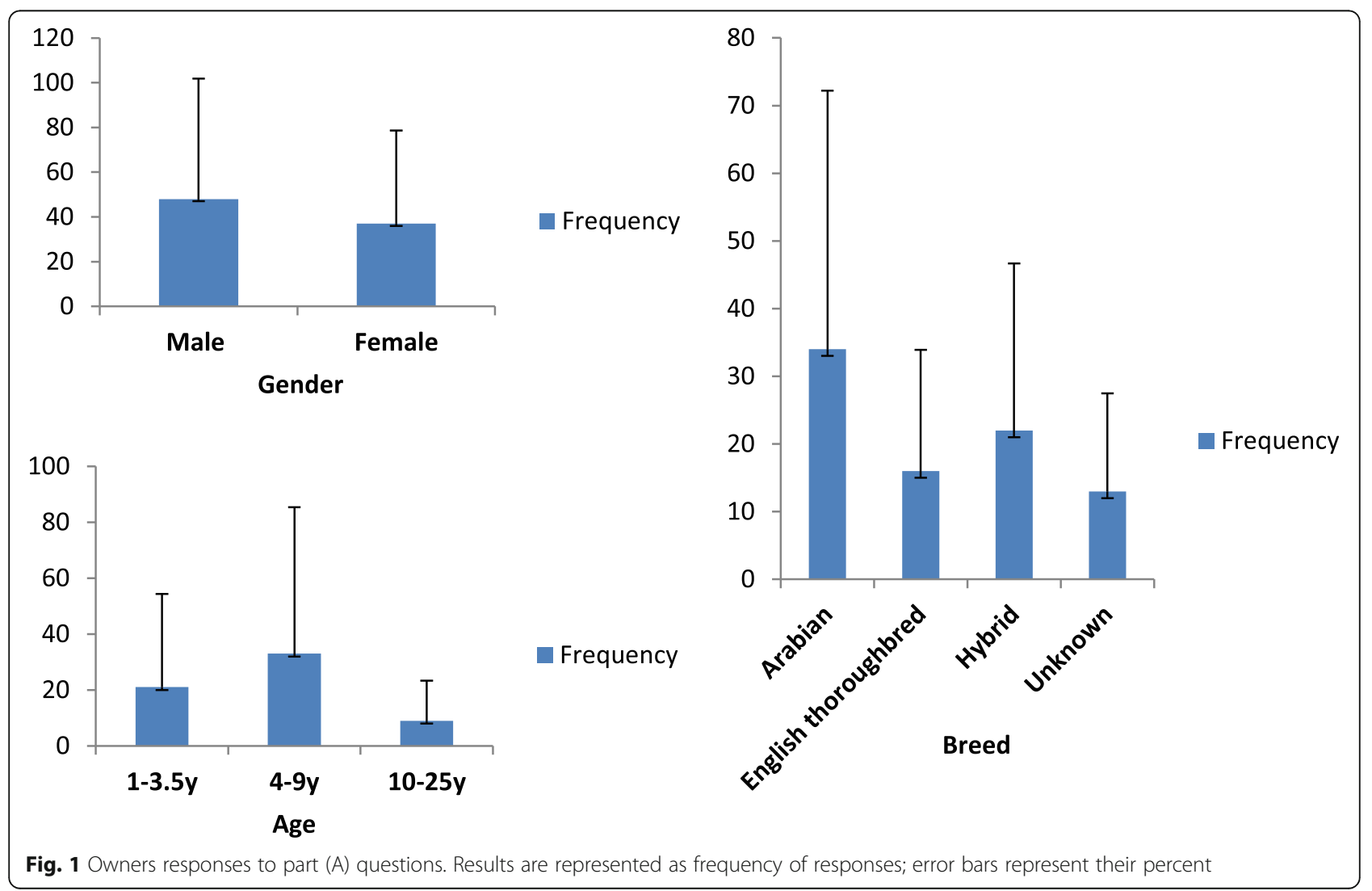


The breeds of horses included in the study are also presented, revealing that the Arabian breed was predominant among the mentioned breeds (38.2\%). Moreover, the majority of horses were between 4 and 9 years old (52.38\%).

Figure 2 shows the respondents' answers to the questions in Part B about the horses' color, head and body marks, leg marks, and whorls. A variety of horse colors were reported, but chestnut was the most common (34.1\%). Most of the studied horses had white marks on the head and body $(61.8 \%)$ and legs $(66.3 \%)$, and the majority had a single whorl (76.4\%). Table 1 presents the owners' responses to the question about temperament, with the mean value on a temperament scale (from 1 to 9) being used for each horse. The horses were classified into two categories: higher (from 6 to 10 on the temperament scale) and lower (from 1 to 5 on the temperament scale).

We used the chi-square test for independence to determine whether there were significant associations between the temperament scale score and the horse's sex, age, breed, and body characteristics. The results in Table 2 show statistically significant associations of sex and breed with temperament scale score with $89.7 \%$ and $108.3 \%$ associations, respectively (both $p<0.001$ ). The same table reveals a non-significant association between age and temperament scale score (chi-square $p$ value $=0.58$ ).

Table 3 shows that there were significant associations of body characteristics (color, head and body marks, leg marks, and whorls) with temperament scale score (chisquare $p$ values $<0.001$ ).

\section{Discussion}

In this study, the temperament of horses was assessed using the owners' responses to Part $\mathrm{C}$ of the questionnaire and classified as higher and lower temperament. We also investigated the effects of age, sex, breed, and body characteristics on horses' temperament.

The training of mares can be very different from that of stallions or even geldings as mares are by nature more sensitive [8]. This may be related to the relationship between sex and temperament, which parallels with the results obtained in this study. The results also coincide with the work of Fenner et al. [9], who demonstrated variation in horses' temperament according to their sex, and also with an online survey that revealed that more respondents defined geldings as calm, reliable, trainable, and predictable; and mares as safe, bossy, trainable, willing, and as having a good attitude; while some respondents labeled stallions as being difficult, while a large

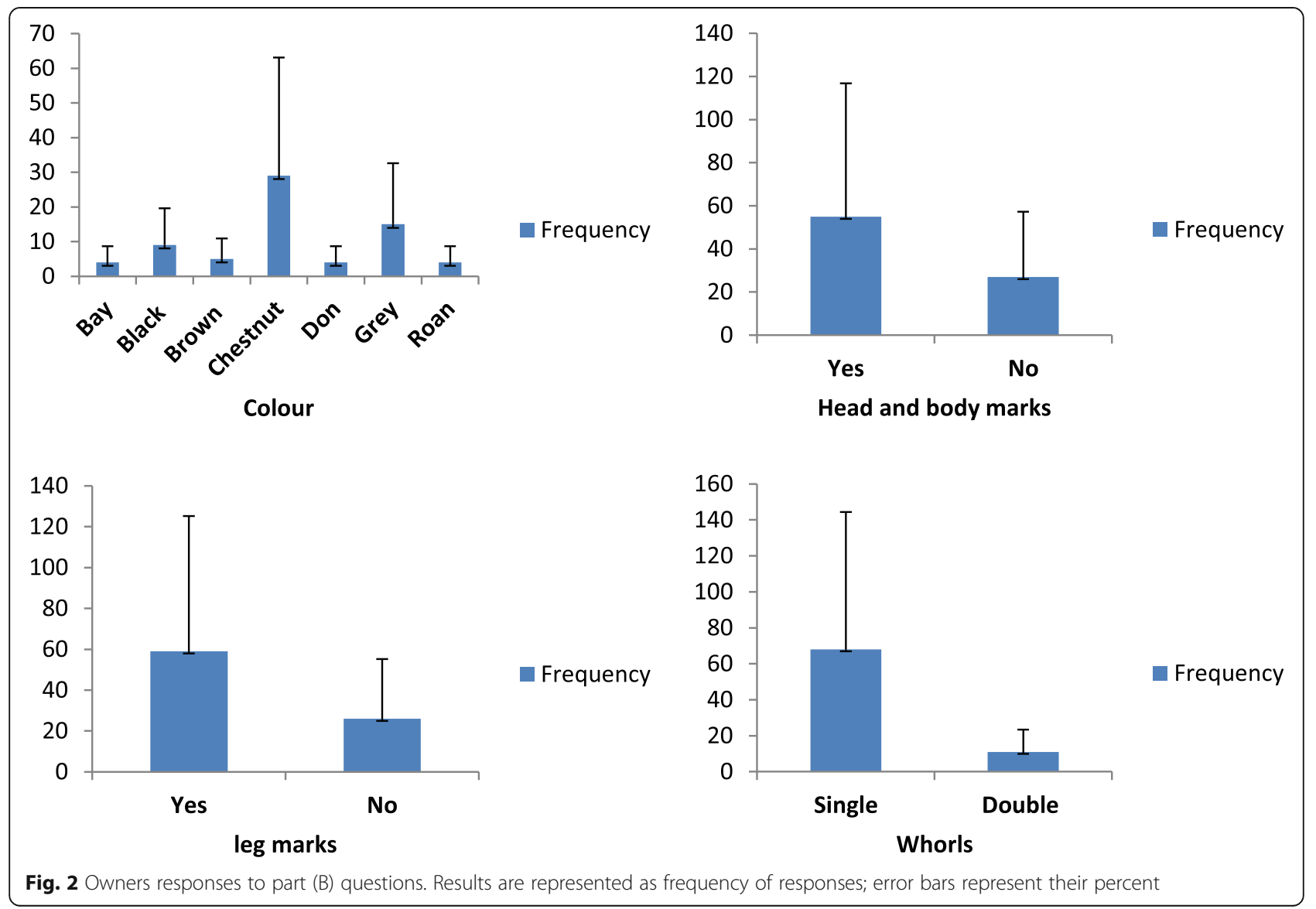


Table 1 Owners responses to part (C) questions (temperament scale questions)

\begin{tabular}{|c|c|c|c|c|c|c|c|c|c|c|c|}
\hline \multirow[t]{2}{*}{ Questions } & \multirow[t]{2}{*}{ Mean } & \multicolumn{9}{|c|}{$\begin{array}{l}\text { Scale frequency } \\
\text { Percent }\end{array}$} & \multirow[t]{2}{*}{$\begin{array}{l}\text { General } \\
\text { orientation }\end{array}$} \\
\hline & & $\begin{array}{l}\text { Totally } \\
\text { agree }\end{array}$ & Agree & $\begin{array}{l}\text { May } \\
\text { agree }\end{array}$ & $\begin{array}{l}\text { To } \\
\text { some } \\
\text { extent }\end{array}$ & Somewhat & $\begin{array}{l}\text { May } \\
\text { disagree }\end{array}$ & Disagree & $\begin{array}{l}\text { Strongly } \\
\text { disagree }\end{array}$ & $\begin{array}{l}\text { Totally } \\
\text { disagree }\end{array}$ & \\
\hline $\begin{array}{l}\text { The horse looks to become } \\
\text { nervous or agitated by new } \\
\text { items, noises }\end{array}$ & 3.39 & $\begin{array}{l}39 \\
46.4\end{array}$ & $\begin{array}{l}8 \\
9.5\end{array}$ & $\begin{array}{l}7 \\
8.3\end{array}$ & $\begin{array}{l}4 \\
4.8\end{array}$ & $\begin{array}{l}4 \\
4.8\end{array}$ & $\begin{array}{l}5 \\
6.0\end{array}$ & $\begin{array}{l}4 \\
4.8\end{array}$ & $\begin{array}{l}2 \\
2.4\end{array}$ & $\begin{array}{l}11 \\
13.1\end{array}$ & May agree \\
\hline $\begin{array}{l}\text { The horse concentrate on } \\
\text { target and unaffected by the } \\
\text { environment }\end{array}$ & 2.52 & $\begin{array}{l}45 \\
54.2\end{array}$ & $\begin{array}{l}14 \\
16.9\end{array}$ & $\begin{array}{l}7 \\
8.4\end{array}$ & $\begin{array}{l}4 \\
4.8\end{array}$ & $\begin{array}{l}2 \\
2.4\end{array}$ & $\begin{array}{l}2 \\
2.4\end{array}$ & $\begin{array}{l}1 \\
1.2\end{array}$ & $\begin{array}{l}2 \\
2.4\end{array}$ & $\begin{array}{l}6 \\
7.2\end{array}$ & Agree \\
\hline $\begin{array}{l}\text { The horse looks to be at ease if } \\
\text { left solo away from the herd. }\end{array}$ & 2.88 & $\begin{array}{l}40 \\
50.6\end{array}$ & $\begin{array}{l}6 \\
7.6\end{array}$ & $\begin{array}{l}12 \\
15.2\end{array}$ & $\begin{array}{l}6 \\
7.6\end{array}$ & $\begin{array}{l}3 \\
3.8\end{array}$ & $\begin{array}{l}1 \\
1.3\end{array}$ & $\begin{array}{l}1 \\
1.3\end{array}$ & $\begin{array}{l}2 \\
2.5\end{array}$ & $\begin{array}{l}8 \\
10.1\end{array}$ & Agree \\
\hline $\begin{array}{l}\text { The horse could be trained } \\
\text { easily. }\end{array}$ & 2.65 & $\begin{array}{l}43 \\
51.2\end{array}$ & $\begin{array}{l}14 \\
16.7\end{array}$ & $\begin{array}{l}6 \\
7.1\end{array}$ & $\begin{array}{l}5 \\
6.0\end{array}$ & $\begin{array}{l}4 \\
4.8\end{array}$ & $\begin{array}{l}3 \\
3.6\end{array}$ & $\begin{array}{l}2 \\
2 . \%\end{array}$ & $\begin{array}{l}1 \\
1.2\end{array}$ & $\begin{array}{l}6 \\
7.1\end{array}$ & Agree \\
\hline $\begin{array}{l}\text { The horse looks to get } \\
\text { energized easily or reacts too } \\
\text { quickly to new stimuli }\end{array}$ & 3.48 & $\begin{array}{l}30 \\
36.1\end{array}$ & $\begin{array}{l}16 \\
19.3\end{array}$ & $\begin{array}{l}8 \\
9.6\end{array}$ & $\begin{array}{l}6 \\
7.2\end{array}$ & $\begin{array}{l}4 \\
4.8\end{array}$ & $\begin{array}{l}2 \\
2.4\end{array}$ & $\begin{array}{l}2 \\
2.4\end{array}$ & $\begin{array}{l}2 \\
2.4\end{array}$ & $\begin{array}{l}13 \\
15.7\end{array}$ & May agree \\
\hline $\begin{array}{l}\text { The horse looks to be never } \\
\text { aggressive or frightful of } \\
\text { individual }\end{array}$ & 1.98 & $\begin{array}{l}61 \\
71.8\end{array}$ & $\begin{array}{l}11 \\
12.9\end{array}$ & $\begin{array}{l}0 \\
0.0\end{array}$ & $\begin{array}{l}2 \\
2.4\end{array}$ & $\begin{array}{l}2 \\
2.4\end{array}$ & $\begin{array}{l}2 \\
2.4\end{array}$ & $\begin{array}{l}3 \\
3.5\end{array}$ & $\begin{array}{l}1 \\
1.2\end{array}$ & $\begin{array}{l}3 \\
3.5\end{array}$ & $\begin{array}{l}\text { Totally } \\
\text { agree }\end{array}$ \\
\hline $\begin{array}{l}\text { The horse looks to be } \\
\text { concentrated in novel objects } \\
\text { and approaches them }\end{array}$ & 3.24 & $\begin{array}{l}36 \\
43.4\end{array}$ & $\begin{array}{l}10 \\
12.0\end{array}$ & $\begin{array}{l}11 \\
13.3\end{array}$ & $\begin{array}{l}4 \\
4.8\end{array}$ & $\begin{array}{l}5 \\
6.0\end{array}$ & $\begin{array}{l}3 \\
3.6\end{array}$ & $\begin{array}{l}2 \\
2.4\end{array}$ & $\begin{array}{l}1 \\
1.2\end{array}$ & $\begin{array}{l}11 \\
13.3\end{array}$ & May agree \\
\hline $\begin{array}{l}\text { The horse looks to remember } \\
\text { what it was trained }\end{array}$ & 1.91 & $\begin{array}{l}54 \\
64.3\end{array}$ & $\begin{array}{l}14 \\
16.7\end{array}$ & $\begin{array}{l}7 \\
8.3\end{array}$ & $\begin{array}{l}2 \\
2.4\end{array}$ & $\begin{array}{l}1 \\
1.2\end{array}$ & $\begin{array}{l}3 \\
3.6\end{array}$ & $\begin{array}{l}0 \\
0.0\end{array}$ & $\begin{array}{l}0 \\
00 ;\end{array}$ & $\begin{array}{l}3 \\
3.6\end{array}$ & $\begin{array}{l}\text { Totally } \\
\text { agree }\end{array}$ \\
\hline $\begin{array}{l}\text { The horse looks to get fearful } \\
\text { to an unusual extent }\end{array}$ & 3.89 & $\begin{array}{l}27 \\
32.1\end{array}$ & $\begin{array}{l}10 \\
11.9\end{array}$ & $\begin{array}{l}8 \\
9.5\end{array}$ & $\begin{array}{l}6 \\
7.1\end{array}$ & $\begin{array}{l}10 \\
11.9\end{array}$ & $\begin{array}{l}4 \\
4.8\end{array}$ & $\begin{array}{l}4 \\
4.8\end{array}$ & $\begin{array}{l}5 \\
6.0\end{array}$ & $\begin{array}{l}10 \\
11.9\end{array}$ & May agree \\
\hline $\begin{array}{l}\text { The horse looks to be } \\
\text { cooperative with a caretaker } \\
\text { when handled }\end{array}$ & 2.37 & $\begin{array}{l}49 \\
59.0\end{array}$ & $\begin{array}{l}13 \\
15.7\end{array}$ & $\begin{array}{l}6 \\
7.2\end{array}$ & $\begin{array}{l}2 \\
2.4\end{array}$ & $\begin{array}{l}2 \\
2.4\end{array}$ & $\begin{array}{l}1 \\
1.2\end{array}$ & $\begin{array}{l}4 \\
4.8\end{array}$ & $\begin{array}{l}2 \\
2.4\end{array}$ & $\begin{array}{l}4 \\
4.8\end{array}$ & Agree \\
\hline $\begin{array}{l}\text { The horse looks to be unstable } \\
\text { from day to day. }\end{array}$ & 4.52 & $\begin{array}{l}23 \\
27.1\end{array}$ & $\begin{array}{l}5 \\
5.9\end{array}$ & $\begin{array}{l}9 \\
10.6\end{array}$ & $\begin{array}{l}9 \\
10.6\end{array}$ & $\begin{array}{l}10 \\
11.8\end{array}$ & $\begin{array}{l}3 \\
3.5\end{array}$ & $\begin{array}{l}6 \\
7.1\end{array}$ & $\begin{array}{l}1 \\
1.2\end{array}$ & $\begin{array}{l}19 \\
22.4\end{array}$ & $\begin{array}{l}\text { To some } \\
\text { extent }\end{array}$ \\
\hline $\begin{array}{l}\text { The horse looks to be tenacious } \\
\text { once it resists a command. }\end{array}$ & 4.08 & $\begin{array}{l}28 \\
32.9\end{array}$ & $\begin{array}{l}9 \\
10.6\end{array}$ & $\begin{array}{l}13 \\
15.3\end{array}$ & $\begin{array}{l}5 \\
5.9\end{array}$ & $\begin{array}{l}3 \\
3.5\end{array}$ & $\begin{array}{l}3 \\
3.5\end{array}$ & $\begin{array}{l}2 \\
2.4\end{array}$ & $\begin{array}{l}3 \\
3.5\end{array}$ & $\begin{array}{l}19 \\
22.4\end{array}$ & $\begin{array}{l}\text { To some } \\
\text { extent }\end{array}$ \\
\hline $\begin{array}{l}\text { The horse looks to be } \\
\text { easygoing in general. }\end{array}$ & 3.22 & $\begin{array}{l}40 \\
47.6\end{array}$ & $\begin{array}{l}10 \\
11.9\end{array}$ & $\begin{array}{l}6 \\
7.1\end{array}$ & $\begin{array}{l}4 \\
4.8\end{array}$ & $\begin{array}{l}5 \\
6.0\end{array}$ & $\begin{array}{l}3 \\
3.6\end{array}$ & $\begin{array}{l}4 \\
4.8\end{array}$ & $\begin{array}{l}2 \\
2.4\end{array}$ & $\begin{array}{l}10 \\
11.9\end{array}$ & May agree \\
\hline $\begin{array}{l}\text { The horse looks to be attentive } \\
\text { about vicinities. }\end{array}$ & 2.29 & $\begin{array}{l}47 \\
56.0\end{array}$ & $\begin{array}{l}15 \\
17.9\end{array}$ & $\begin{array}{l}7 \\
8.3\end{array}$ & $\begin{array}{l}3 \\
3.6\end{array}$ & $\begin{array}{l}2 \\
2.4\end{array}$ & $\begin{array}{l}4 \\
4.8\end{array}$ & $\begin{array}{l}1 \\
1.2\end{array}$ & $\begin{array}{l}3 \\
3.6\end{array}$ & $\begin{array}{l}2 \\
2.4\end{array}$ & Agree \\
\hline The horse looks to be patient & 2.9 & $\begin{array}{l}34 \\
40.5\end{array}$ & $\begin{array}{l}15 \\
17.9\end{array}$ & $\begin{array}{l}7 \\
8.3\end{array}$ & $\begin{array}{l}10 \\
11.9\end{array}$ & $\begin{array}{l}9 \\
10.7\end{array}$ & $\begin{array}{l}1 \\
1.2\end{array}$ & $\begin{array}{l}2 \\
2.4\end{array}$ & $\begin{array}{l}0 \\
0.0\end{array}$ & $\begin{array}{l}6 \\
7.1\end{array}$ & Agree \\
\hline $\begin{array}{l}\text { The horse looks to socialize } \\
\text { with other horses in a friendly } \\
\text { way }\end{array}$ & 3.9 & $\begin{array}{l}28 \\
35.0\end{array}$ & $\begin{array}{l}8 \\
10.0\end{array}$ & $\begin{array}{l}7 \\
8.8\end{array}$ & $\begin{array}{l}5 \\
6.3\end{array}$ & $\begin{array}{l}9 \\
11.3\end{array}$ & $\begin{array}{l}5 \\
6.3\end{array}$ & $\begin{array}{l}3 \\
3.8\end{array}$ & $\begin{array}{l}3 \\
3.8\end{array}$ & $\begin{array}{l}12 \\
15.0\end{array}$ & May agree \\
\hline $\begin{array}{l}\text { The horse looks to be dominant } \\
\text { in fighting with other horses. }\end{array}$ & 3.7 & $\begin{array}{l}26 \\
33.8\end{array}$ & $\begin{array}{l}6 \\
7.8\end{array}$ & $\begin{array}{l}10 \\
13.0\end{array}$ & $\begin{array}{l}6 \\
7.8\end{array}$ & $\begin{array}{l}11 \\
14.3\end{array}$ & $\begin{array}{l}3 \\
3.9\end{array}$ & $\begin{array}{l}6 \\
7.8\end{array}$ & $\begin{array}{l}2 \\
2.6\end{array}$ & $\begin{array}{l}7 \\
9.1\end{array}$ & May agree \\
\hline $\begin{array}{l}\text { The horse looks to get } \\
\text { surprised in an easy manner. }\end{array}$ & 3.75 & $\begin{array}{l}30 \\
37.5\end{array}$ & $\begin{array}{l}5 \\
6.3\end{array}$ & $\begin{array}{l}9 \\
11.3\end{array}$ & $\begin{array}{l}11 \\
13.8\end{array}$ & $\begin{array}{l}5 \\
6.3\end{array}$ & $\begin{array}{l}3 \\
3.8\end{array}$ & $\begin{array}{l}1 \\
1.3\end{array}$ & $\begin{array}{l}5 \\
6.3\end{array}$ & $\begin{array}{l}11 \\
13.8\end{array}$ & May agree \\
\hline $\begin{array}{l}\text { The horse looks to be lacks } \\
\text { bravery in new environments. }\end{array}$ & 4.47 & $\begin{array}{l}20 \\
23.5\end{array}$ & $\begin{array}{l}8 \\
9.4\end{array}$ & $\begin{array}{l}12 \\
14.1\end{array}$ & $\begin{array}{l}9 \\
10.6\end{array}$ & $\begin{array}{l}9 \\
10.6\end{array}$ & $\begin{array}{l}2 \\
2.4\end{array}$ & $\begin{array}{l}3 \\
3.5\end{array}$ & $\begin{array}{l}4 \\
4.7\end{array}$ & $\begin{array}{l}18 \\
21.2\end{array}$ & $\begin{array}{l}\text { To some } \\
\text { extent }\end{array}$ \\
\hline $\begin{array}{l}\text { The horse can be load easily } \\
\text { into a trailer. }\end{array}$ & 3.4 & $\begin{array}{l}38 \\
45.2\end{array}$ & $\begin{array}{l}9 \\
10.7\end{array}$ & $\begin{array}{l}8 \\
9.5\end{array}$ & $\begin{array}{l}1 \\
1.2\end{array}$ & $\begin{array}{l}7 \\
8.3\end{array}$ & $\begin{array}{l}4 \\
4.8\end{array}$ & $\begin{array}{l}3 \\
3.6\end{array}$ & $\begin{array}{l}2 \\
2.4\end{array}$ & $\begin{array}{l}12 \\
14.3\end{array}$ & May agree \\
\hline
\end{tabular}

Results are represented as mean, frequency, and the percent of respondent 
Table 2 Association between temperament scale and horse's gender, breed, and age

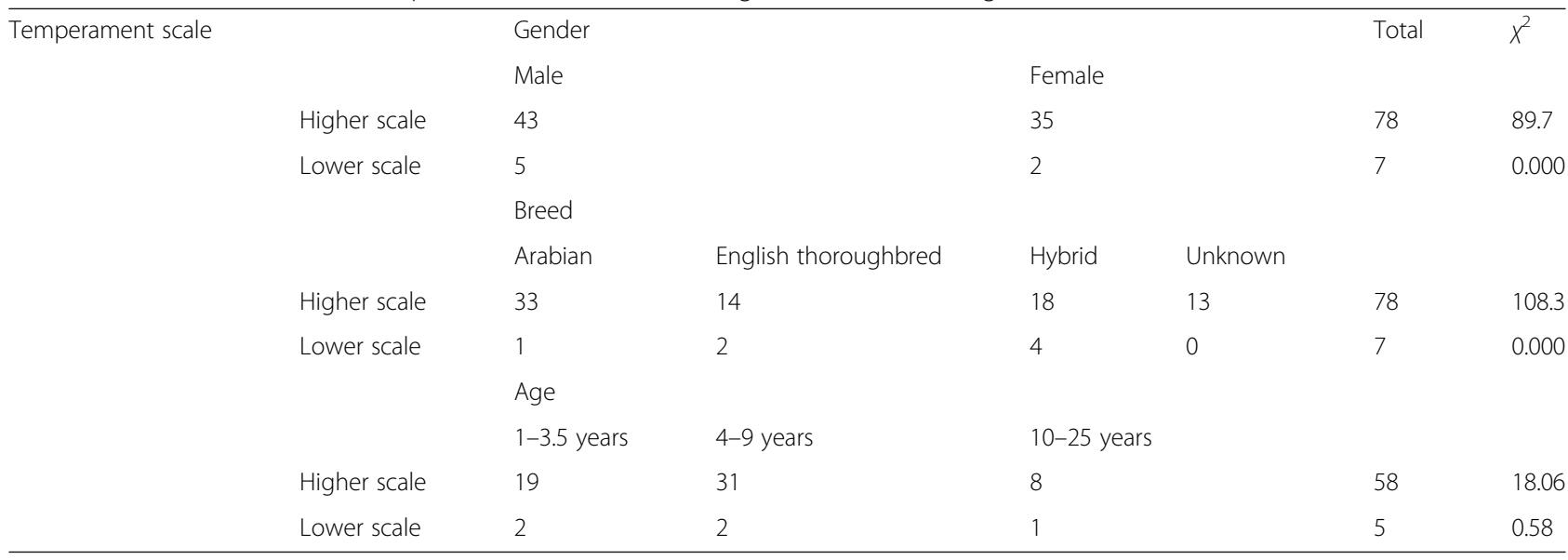

Results are represented as a frequency

$X^{2}$ is represented as Pearson's chi-square value and significance

proportion of them labeled stallions as being bossy, trainable, and having a good attitude.

A horse's breed was found to have a direct association with its temperament. This is in accordance with the work of Hausberger and Muller [10], Hausberger et al. [11], and Lloyd et al. [12], who showed that breed can affect a horse's reactions toward humans. It is therefore predicted that horse breeds differ in their personalities.

Regarding the relationship between age and temperament, the obtained results are to some extent consistent with the work of Jezierski et al. [13], who showed that 2year-old horses were less manageable than younger ones.
A horse's coat color has long been considered to reflect its temperament [14]. The results in this study suggest that silver horses are more cautious in novel situations, rather than more reactive in fearful situations. They also revealed the relatively common opinion that different coat colors are related to personality traits such as calmness, boldness, or nervousness. Furthermore, Lauren et al. [15] reported that black mares were more independent than bay mares. This to some extent agrees with our results that suggested a relationship between a horse's coat color and its temperament. Lauren et al. [15] explained the relationship between coat color and temperament as being associated with the shared signaling pathways utilized by neurons and melanocytes,

Table 3 Association between temperament scale and horse's body characteristics

\begin{tabular}{|c|c|c|c|c|c|c|c|c|c|c|}
\hline \multirow{2}{*}{\multicolumn{2}{|c|}{ Temperament scale }} & \multicolumn{7}{|c|}{ Color } & \multirow[t]{2}{*}{ Total } & \multirow[t]{2}{*}{$x^{2}$} \\
\hline & & Bay & Black & Brown & Chestnut & Don & Gray & Roan & & \\
\hline & Higher scale & 4 & 7 & 5 & 28 & 2 & 15 & 4 & 65 & 15.47 \\
\hline & Lower scale & & 2 & & 1 & 1 & & & 4 & 0.000 \\
\hline & & \multicolumn{7}{|c|}{ Head and body marks } & & \\
\hline & & \multicolumn{4}{|l|}{ Yes } & \multicolumn{3}{|l|}{ No } & & \\
\hline & Higher scale & \multicolumn{4}{|l|}{50} & \multicolumn{3}{|l|}{26} & 76 & 63.16 \\
\hline & Lower scale & \multicolumn{4}{|l|}{5} & \multicolumn{3}{|l|}{2} & 7 & 0.000 \\
\hline & & \multicolumn{7}{|c|}{ Leg marks } & & \\
\hline & & \multicolumn{4}{|l|}{ Yes } & \multicolumn{3}{|l|}{ No } & & \\
\hline & Higher scale & \multicolumn{4}{|l|}{52} & \multicolumn{3}{|l|}{26} & 78 & 93.59 \\
\hline & Lower scale & \multicolumn{4}{|l|}{7} & \multicolumn{3}{|l|}{0} & 7 & 0.000 \\
\hline & & \multicolumn{7}{|c|}{ Whorls } & & \\
\hline & & \multicolumn{4}{|l|}{ Yes } & \multicolumn{3}{|l|}{ No } & & \\
\hline & Higher scale & \multicolumn{4}{|l|}{10} & \multicolumn{3}{|l|}{62} & 72 & 33.47 \\
\hline & Lower scale & \multicolumn{4}{|l|}{1} & \multicolumn{3}{|l|}{6} & 7 & 0.000 \\
\hline
\end{tabular}


resulting in pleiotropic traits of coat color and behavior in many mammalian species.

Hair whorls in horses (rosettes) are considered a constant form of identification for horses, since a whorl does not change in direction or location during a horse's lifetime. Whorls can thus be considered the equine tantamount of fingerprints in humans [16].

The higher frequency of high-scale temperament in horses with double whorls than in those with single ones is in agreement with the work of Linda and Sybil [16], who reported that horses with two whorls, either side by side or one above the other, tend to be more reactive than average. They also tend to become disturbed for no apparent reason, and at unexpected moments. The findings also agree with a previous study [17] that noted that horses with double whorls on the face tend to be overly reactive or highly strung to novel stimuli. The relationship between temperament and this body characteristic has also been explained by research showing that skin and brain tissue come from the same layer of cells (ectoderm) during embryonic development. As embryonic cells migrate to form the fetus, skin and brain cells are closely intertwined, particularly at the scalp, explaining how this hair formation could be related to personality. It was also added that, although hair whorls cannot completely predict a horse's temperament or performance, they might be worth taking into consideration when purchasing horses.

\section{Conclusions}

Temperament is an important issue that should be taken into consideration when purchasing horses for leisure, racing, or even work in the fields. This questionnairebased study proved that purchasers can predict a horse's temperament from its sex, breed, and body characteristics, including coat color, body and leg marks, and whorls.

\section{Acknowledgements}

Not applicable

\section{Authors' contributions}

N.A. was a major contributor in preparing the research work and writing the manuscript. H.E. contributes in the methods of the study and reviewing the manuscript. All authors read and approved the final manuscript.

\section{Funding}

Not applicable

\section{Availability of data and materials}

The datasets generated during and/or analyzed during the current study are available from the corresponding author on reasonable request.

\section{Declarations}

Ethics approval and consent to participate Not applicable
Consent for publication

Not applicable

\section{Competing interests}

The authors declare that they have no competing interests

Received: 7 June 2021 Accepted: 29 July 2021

Published online: 18 August 2021

\section{References}

1. Pervin LA, John OP (1997) Personality: Theory and research, 7th edn. John Wiley \& Sons

2. Helmbrecht Howard T.M. (2016) Equine assisted activities and therapies: The measuring of equine temperament. phD in health psychology, Walden University.

3. Olsson K. (2010) A review of methods used to measure temperamental characteristics in horses. Degree project ethology july 2010.doc. https://stud. epsilon.slu.se/1575/1/olsson_k_100706.pdf

4. Hennessy KD, Quinn KM, Murphy J (2008) Producer or purchaser: Different expectations may lead to equine wastage and welfare concerns. J Appl Anim Welf Sci. 11(232-235):3. https://doi.org/10.1080/10888700802101023

5. Patricia G, Borstel UKV, Gauly (2013) Importance of personality traits in horses to breeders and riders. J Vet Behav. 8:316-325

6. Visser EK, van Reenen CG, Rundgren M, Zetterqvist M, Morgan K, Blokhuis HJ (2003) Responses of horses in behavioural tests correlate with temperament assessed by riders. Equine Vet. J. 35(176-183):2. https://doi. org/10.2746/042516403776114108

7. Momozawa Y, Ono T, Sato F, Kikusui T, Takeuchi Y, Mori Y, Kusunose R (2003) Assessment of equine temperament by a questionnaire survey to caretakers and evaluation of its reliability by simultaneous behavior test. Appl. Anim. Behav. Sci. 84(127-138):2. https://doi.org/10.1016/j.applanim.2 003.08.001

8. Mary AS (2013) Assessing your horse's temperament. Between the ears a sidelines blog by Mary Ann Simonds, MA-Exploring horse-rider psychology. https://sidelinesmagazine.com/blogs/betweentheears/

9. Fenner K., Casper G., Hyde M., Henshall C., Dhand N., Probyn-Rapsey F., Dashper K., McGreevy P. (2019) it's all about the sex: Preconceived ideas about horse temperament based on human gender and horse sex. Conference Paper. Journal of Veterinary Behavior 29.

10. Hausberger M, Muller C (2002) A brief note on some possible factors involved in the reactions of horses to humans. Appl. Anim. Behav. Sci. 76(339-344):4. https://doi.org/10.1016/S0168-1591(02)00016-3

11. Hausberger M, Bruderer C, Le Scolan N, Pierre JS (2004) Interplay between environmental and genetic factors in temperament/personality traits in horses (Equus caballus). J. Comp. Psychol. 118(434-446):4. https://doi.org/1 0.1037/0735-7036.118.4.434

12. Lloyd AS, Martin JE, Bornett-Gauci HLI, Wilkinson R, G. (2008) Horse personality: Variation between breeds. Appl. Anim. Behav. Sci. 112(369-383): 3-4. https://doi.org/10.1016/j.applanim.2007.08.010

13. Jezierski, T., Jaworski, Z., Gorecka, A. (1999) Effects of handling on behaviour and heart rate in Konik horses: Comparison of stable and forest reared young stock. Appl. Anim. Behav. Sci. 62, 1-11, 1, DOl: https://doi.org/10.101 6/S0168-1591(98)00209-3.

14. Brunberg E., Gillea S., Mikkoc S., Lindgrend G., Keeling L. J. (2013) Icelandic horses with the Silver coat colour show altered behaviour in a fear reaction test. Appl. Anim. Behav. Sci.146, 72-78.

15. Lauren NJ, Elizabeth AS, Julia DA, Samantha AB (2016) The MC1R and ASIP coat color loci may impact behavior in the horse. J. Hered. 107(3):214-219 https://doi.org/10.1093/jhered/esw007

16. Linda T. and Sybil T. (2012) Learning to evaluate character In: Getting in TTouch with your Horse "how to assess and influence personality, potential and performance" pp. 1-9. Copyright Linda Tellington-Jones / Trafalgar Square Books www. Horse and RiderBooks.com.

17. Anna O'Brien, D.V.M. (2015) What your horse's whorl says about him? Scientific research backs up some of the old notions about horses' hair patterns. https://www.horseillustrated.com/horse-news-2015-05-what-yourhorses-whorl-says-about-him

\section{Publisher's Note}

Springer Nature remains neutral with regard to jurisdictional claims in published maps and institutional affiliations. 